\title{
Economy
}

\section{Economy Today}

\section{An Interdisciplinary Approach}

to Contemporary Economic

Challenges

edited by Piotr Urbanek

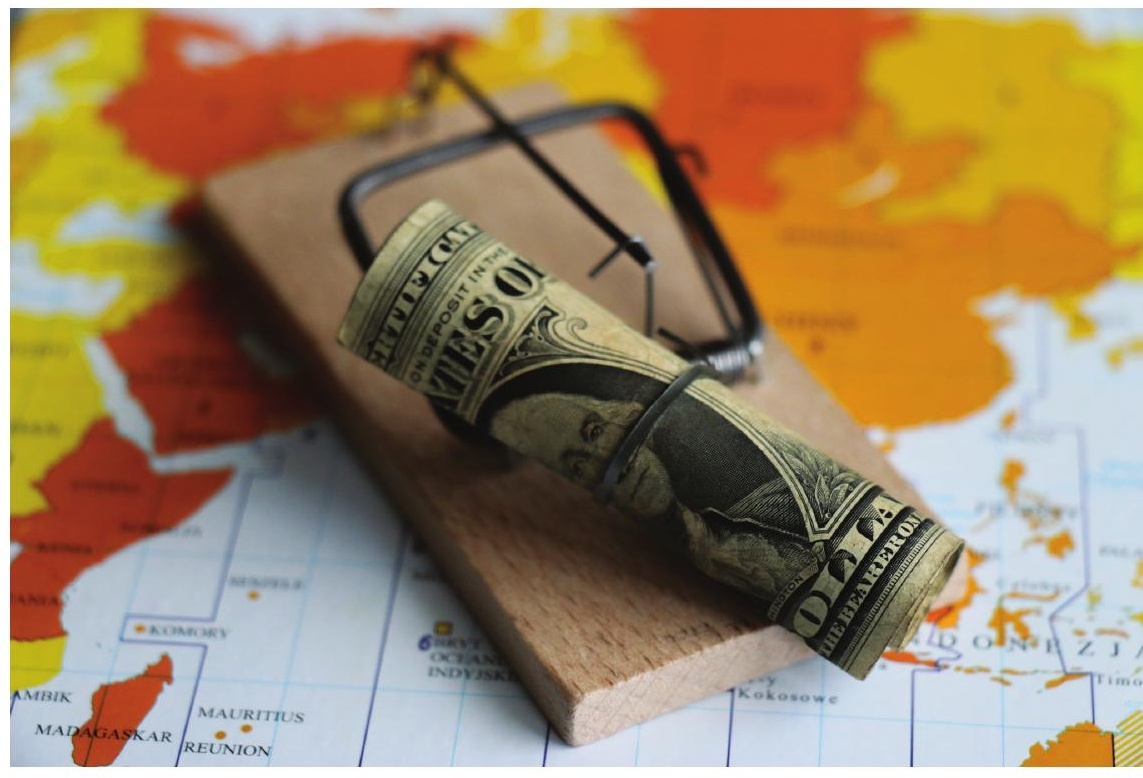




\title{
Processes of global integration and the economic growth
}

\section{Triangle trade relation among China, the EU and Taiwan under the aspect of the WTO}

Li-Jiuan Chen-Rabich, LL.M*

\begin{abstract}
The WTO is a member-driven international trade organization composed of governments and customs territories. It sets the legal framework for trade among the members. The EU as successor of the EC is the founding member since the establishment of the WTO in 1995. With the gradual enlargement process, the EU has been also one of the super members with the strong economic power within the WTO. Since the open and reform towards the world economy, China has taken a rapid step for the economic development in the 1980s. China has accessed into the WTO in Dec. 2001. The Taiwan's economy strongly depends on export. Therefore, trade plays a very important role for Taiwan. Taiwan has become the $144^{\text {th }}$ member of the WTO since 2002 . Nowadays the WTO is an important platform for Taiwan in the international community, especially the Cross-Straits trade relation between China and Taiwan. With the trend of globalization, the trade relation between China
\end{abstract}

* Prof. Dr. Graduate Institute of European Studies, Tamkang University, Taiwan, ROC. 
and Taiwan is unavoidable and inevitable. The Cross-Straits trade relation has rapidly developed after their access into the WTO. As a result, the WTO has become an important platform for the interaction between China and Taiwan. Furthermore, China and Taiwan have concluded in 2009 the Economic Cooperation Framework Agreement (ECFA) under the WTO.

This thesis firstly works on the ECFA as basis to explain its content and its impact on the both-side development. Secondly, it deals with the triangle relation among China, the EU and Taiwan within the WTO. Furthermore, it focuses on the signification of the ECFA for the triangle trade relation and its future. Finally, it draws a conclusion as finding of this research.

\subsection{EU's position in the WTO}

The WTO is a member-driven international trade organization composed of governments and customs territories since the establishment of the WTO in 1995. It sets the legal framework for trade among the members. The European Union (EU) as legal successor of the European Community (EC) is the founding member since the establishment of the WTO in 1995. With the fifth enlargement process in 2004, the EU has been also one of the super members with the strong economic power within the WTO.

The EU has currently 28 member states and its economic power can't be ignored. The EU is one of the most important members of the WTO and plays a leading role within the WTO. The Commission is on behalf of the EU with one voice in the WTO (Meunier, 2005). The EU has a very dynamic development in its history from the customs union, and then common market finally to the economic and monetary union. The EU is the largest economic power in the world. The size of its internal market and its share of world trade invite WTO members to seek deals with the EU, and increasingly to try to adapt to its standards and rules (Meunier and Kalypso, 2006). The EU's leadership role in multilateral negotiation and in shaping the new order is a main channel to direct export its model of regional governance, and to consolidate itself as an important player on the global stage (Santander, 2014).

The Lisbon Treaty has concretely provided the legal personality of the EU. The EU can better than ever participate in the international affairs (Weber, 2008). The Lisbon Treaty has reformed the EU's Common Commercial Policy to contribute to a comprehensive and effective trade policy. Good global governance has become a general model under the multilateral framework of the WTO, especially through the conclusion of the international trade agreement (Pitschas, 2007). The EU has exclusive competence relating to the Common Commercial Policy after the Lisbon Treaty. The Common Commercial Policy includes GATT, GATS and TRIPS within the 
WTO (Hermann et al., 2006). To sum up, the WTO plays an important role in the global governance. The EU has taken part in the global governance by way of the WTO to establish rules for international trade.

\subsection{Global impact on the development of Cross-Straits relation}

The Cross-Straits relation was hostile and in tension since the end of civil war in 1949. Since the open and reform towards the world economy in 1979, China has taken a rapid step for the economic development and introduced a series of reform measures. Due to the open and reform policy, China has established Special Economic Zones ${ }^{1}$ to attract foreign direct investment and introduced many promotion measures for the foreign investments. On the other side, Taiwan has also abolished its Martial Law in 1987. This action has moderated tensions between both sides of the Cross-Straits. It also improved the Cross-Straits trade relation and political peaceful development.

China has accessed into the WTO in Dec. 2001. The Taiwan's economy strongly depends on export. Therefore, trade plays a very important role. Taiwan has become the $144^{\text {th }}$ member of the WTO since 2002. Nowadays the WTO is an important platform for Taiwan in the international community, especially the Cross-Straits trade relation between China and Taiwan. Currently, China is one of the most important trade partners of Taiwan. The WTO has become an important platform for the Cross-Straits trade relation. The two-way trade and investment have rapidly developed.

\subsection{ECFA - New milestone for the Cross-Straits trade relation}

Both China and Taiwan are members of the WTO. Hence, the trade relation has fast developed and additionally contributed to better improving the overall relationship. Furthermore, China and Taiwan ${ }^{2}$ have concluded in 2009 the Economic Cooperation Framework Agreement (ECFA) under the basic principles ${ }^{3}$ of the WTO in order to gradually reduce or eliminate barriers to trade and investment for each other and create a fair trade and

1 The most prominent Special Economic Zones in China are Shenzhen, Xiamen, Shantou and Zhuhai. All are on the southern coast of China where sea is very accessible for transportation of goods.

2 Due to the one-China policy, the Straits Exchange Foundation and the Association for Relations Across the Taiwan Straits are separately representatives for the Chinese Government and the Taiwanese Government who signed the ECFA.

3 Namely principles of equity, reciprocity and progressiveness. 
investment environment, further advance Cross-Straits trade and investment relations ${ }^{4}$. The ECFA contains 16 articles and 5 annexes (Table 1.1).

\begin{tabular}{|c|c|}
\hline Chapter 1 & General Principles \\
\hline Article 1 & Objectives \\
\hline Article 2 & Cooperation Measures \\
\hline Chapter 2 & Trade and Investment \\
\hline Article 3 & Trade in Goods \\
\hline Article 4 & Trade in Services \\
\hline Article 5 & Investment \\
\hline Chapter 3 & Economic Cooperation \\
\hline Article 6 & Economic Cooperation \\
\hline Chapter 4 & Early Harvest \\
\hline Article 7 & Early Harvest for Trade in Goods \\
\hline Article 8 & Early Harvest for Trade in Services \\
\hline Chapter 5 & Other Provisions \\
\hline Article 9 & Exceptions \\
\hline Article 10 & Dispute Settlement \\
\hline Article 11 & Institutional Arrangements \\
\hline Article 12 & Documentation Formats \\
\hline Article 13 & Annexes and Subsequent Arrangements \\
\hline Article 14 & Amendments \\
\hline Article 15 & Entry into Force \\
\hline Article 16 & Termination \\
\hline Annex I & $\begin{array}{l}\text { Product List and Tariff Reduction Arrangements Under the Early Harvest for Trade } \\
\text { in Goods }\end{array}$ \\
\hline Annex II & $\begin{array}{l}\text { Provisional Rules of Origin Applicable to Products Under the Early Harvest for } \\
\text { Trade in Goods }\end{array}$ \\
\hline Annex III & $\begin{array}{l}\text { Safeguard Measures Between the Two Parties Applicable to Products Under the } \\
\text { Early Harvest for Trade in Goods }\end{array}$ \\
\hline Annex IV & Sectors and Liberalization Measures Under the Early Harvest for Trade in Services \\
\hline Annex V & $\begin{array}{l}\text { Definitions of Services Suppliers Applicable to Sectors and Liberalization Mea- } \\
\text { sures Under the Early Harvest for Trade in Services }\end{array}$ \\
\hline
\end{tabular}

Table 1.1. Tables of Contents

Source: ECFA.

4 Preamble of the ECFA. 
The ECFA is by nature a stage agreement what provides a frame of contents and schedule for the future negotiation. China and Taiwan are politically still in a state of hostility, but in reality they have very close trade relation. It is inevitable to have a further cooperation framework agreement under the WTO. Therefore, the ECFA plays a very important role for the development and improvement of the Cross-Straits relationship. The ECFA has crested a cooperation mechanism between China and Taiwan. In other words, the ECFA is a basic agreement for the economic cooperation between China and Taiwan. The ECFA is also mutual beneficial to the Cross-Straits relationship.

To strengthen Cross-Straits economic exchange and cooperation, following measures are taken (Art. 2 of the ECFA):

1. Gradually reducing or eliminating restrictions on a large number of sectors in trade and in services.

2. Providing investment protection and promoting two-way investment.

3. Promoting trade and investment facilitation and industry exchanges and cooperation.

The ECFA has come into force on the Sep. $12^{\text {th }}$, 2010. Due to the nature of framework agreement with overall objectives, China and Taiwan have continued negotiations relating to trade in goods and in services, investment protection and so on. The agreement on trade in goods includes modalities for tariff reduction or elimination, rules of origin, customs procedures, non-tariff measures ${ }^{5}$ and trade remedy measures (Art. 3 II of the ECFA). The agreement on trade in services shall seek to (1) gradually reduce or eliminate restrictions on a large number of sectors in trade in services; (2) further increase the breadth and depth of trade in services; (3) enhance cooperation in trade in services (Art. 4 II of the ECFA). The agreement on investment includes (1) establishing an investment protection mechanism; (2) increasing transparency on investment-related regulations; (3) gradually reducing restrictions on mutual investments; (4) promoting investment facilitation (Art. 5 II of the ECFA). The both - side economic cooperation relates to following areas (Art. 6 I of the ECFA):

(1) Intellectual property rights protection and cooperation;

(2) Financial cooperation;

(3) Trade promotion and facilitation;

(4) Customs cooperation;

(5) E-commerce cooperation;

(6) Discussion on the overall arrangements and key areas for industrial cooperation, promotion of cooperation in major projects, and

5 Such as technical barriers to trade (TBT) and sanitary and phytosanitary (SPS) measures. 
coordination of the resolution of issues that may arise in the course of industrial cooperation;

(7) Promotion of small and medium-sized enterprises cooperation and enhancement of the competitiveness of these enterprises;

(8) Promotion of the mutual establishment of offices by economic and trade bodies of the two parties.

It is worthy to mention the establishment of appropriate dispute settlement procedures, namely a Cross-Straits Economic Cooperation Committee has been established to settle any dispute arising from the interpretation, implementation and application of the ECFA (Art. 10 and Art. 11 of the ECFA).

To sum up, the ECFA covers an overall economic cooperation between China and Taiwan. The application scope of the ECFA is comprehensive including industrial production, investment, services (banking, financial industry, insurance etc.) and intellectual property protection.

\subsection{Impact of the ECFA on the European enterprises}

The ECFA plays a role of new milestone for the Cross-Straits trade relation. China has shown its economic power after the transition since its entry into the WTO in 2001. China is currently a mega partner in the world trade, but it has still communist regime. On the other hand, Taiwan has a democratic system with rule of law. Especially, Taiwan has adopted the German legal system and also a typical continental legal system.

The role of EU's investment is not only as assistance for economic development, but also extension of market and promotion of economic growth. The EU is nowadays a strong economic unit in the international community. The EU is one of the most important foreign investors for both China and Taiwan. The peaceful atmosphere between the CrossStraits is also very positive and advantageous for the European enterprises. In particular, the European enterprises need an export market for the economic recovery and growth after the global financial crisis.

After the 10-year transition period, China has transformed into a trade-driven country. Although China is still a communist country, China has to oblige its commitments of the WTO. Therefore, China has constantly reformed its economic structure and market system. With the reform measures, China has become a mega factory in the world. China has step by step participated in the world economy. China has also adopted the rules of international trade law. China's plan economy has been transformed into the market economy. Unfortunately, China is still a communist country. 
To a certain extent, China is still a totalitarian state. On the contrary, Taiwan has ended with its totalitarian regime after the abolition of the Martial Law in 1987. There were also introduced a series of reform measures. Nowadays Taiwan has a free, democratic and open society. In fact, Taiwan has accepted universal values provided in Art. 2 of the Treaty of the European Union. Taiwan traditionally has adopted the German legal system, in particular constitution, civil law, business law, employment law, cooperation law, intellectual property law and so on. Taiwan has amended lots of outdated rules to fulfill its commitments after the access into the WTO. Taiwan has always an open society, therefore Taiwan offers an advantageous business environment for European enterprises.

\section{Conclusion}

The WTO is the most important platform and legal framework in the global governance. The triangle trade relation among China, the EU and Taiwan has recently well developed. The ECFA between China and Taiwan under the WTO framework is a new milestone for the development of the Cross-Straits relation. China has transformed its plan economy into the market economy after the access into the WTO, but China is still a communist regime. On the contrary, Taiwan has a democratic and open society. In fact, China and Taiwan have the same culture and language. The ECFA offers a very useful business environment for European enterprises. As a result, the European enterprises can establish headquarter for their business of the Chinese-speaking area in Taiwan and take advantage of the ECFA. The ECFA is very positive and advantageous for the triangle trade relation among China, the EU and Taiwan.

\section{References}

Hermann Ch., Krenzler H.G., Streinz R. (2006), Die Aussenwirtschaftspolitik der EU nach dem Verfassungsvertrag, Verlag C.H. Beck, München.

Meunier S. (2005), Trading Voices: The European Union in International Commercial Negotiations, Princeton University Press, Princeton-Oxford.Meunier S., Kalypso N. (2006), The European Union as a conflicted trade power, "Journal of European Public Policy", Vol. 13, No. 6, p. 906-925.

Pitschas R. (2007), Handel and Entwicklung im Zeichen der WTO, Duncker \& Humbolt, Berlin.

Santander S. (2014), The EU in the Shifts of Power in the International Order: Challenges and Responses, "European Foreign Affairs Review”, Vol. 19, No. 1. Weber A. (2008), Vom Verfassungsvertrag zum Vertrag von Lissabon, EuZW. 
The book fits into a multidisciplinary research approach. The articles are the result of research conducted by eminent international economists, authors representing academic centres in different countries. The articles address current phenomena observed in the global economy. The authors do not aspire to comprehensively explain all the very complex and multi-dimensional economic developments, but illustrate many of these phenomena in an original way. The multi-threaded and multi-dimensional nature of the discussion in particular articles deserves attention. These include theoretical and methodological articles as well as the results of empirical research presented by the authors.

The book is addressed to those persons interested in issues of economics, finance, regional economy, and the management sciences. It can be valuable for economic practitioners, members of management and supervisory boards of companies, and financial analysts, and the articles may also be useful for academicians and students.

Piotr Urbanek, University of Łódź

\section{NBP Narodowy Bank Polski}

